\title{
ANALISIS POTENSI EKONOMI KABUPATEN SUMBAWA TAHUN 2011-2016
}

\author{
Analysis of the Economic Potential of Sumbawa Regency in 2011-2016 \\ ${ }^{1}$ Wahyu Pratama, ${ }^{2}$ Fitriah Permata Cita, ${ }^{3}$ Edi irawan
}

\author{
${ }^{1}$ Fakultas Ekonomi dan Bisnis Universitas Teknologi Sumbawa ${ }^{2}$ Dosen Fakultas Ekonomi dan Bisnis Universitas \\ Teknologi Sumbawa ${ }^{3}$ Dosen Fakultas Ekonomi dan Bisnis Universitas Teknologi Sumbawa \\ Email : Pratamawahyu417@gmail.com
}

\begin{abstract}
Abstrak
Penelitian ini bertujuan untuk menganalisa sektor manakah yang menjadi sektor unggulan di Kabupaten Sumbawa tahun 2011 2016, mengetahui struktur ekonomi (National Share, Proportional Shift dan Differential Shift) Kabupaten Sumbawa tahun 2011. 2016, mengetahui pertumbuhan sektor perekonomian yang ada di Kabupaten Sumbawa tahun 2011-2016. Alat analisis yang digunakan adalah analisis Location Quotient (LQ), analisis Shift Share dan analisis Tipologi Klassen. Berdasarkan alat analisis di atas di peroleh bahwa sektor unggulan di Kabupaten Sumbawa tahun 2011-2016 adalah : sektor pertanian kehutanan dan perikanan, sektor konstruksi, sektor jasa perusahaan, sektor pengadaan listrik dan gas, sektor perdagangan besar dan eceran, reparasi sepeda motor dan mobil, sektor jasa keuangan dan asuransi, sektor administrasi pemerintahan, pertahanan dan jaminan sosial wajib, dan sektor jasa pendidikan. Bagian terbesar dari struktur ekonomi Kabupaten Sumbawa adalah sektor pertanian kehutanan dan perikanan, sedangkan yang terkecil adalah sektor pengadaan air dan pengolaha sampah, limbah dan daur ulang. Proportional Shift memiliki sepuluh sektor yang bertanda negatif dan memiliki tujuh sektor yang bertanda positif. Differential Shift memiliki sebelas sektor yang bertanda negatif dan memiliki enam sektor yang bertanda positif. Dan pertumbuhan ekonomi Kabupaten Sumbawa ada empat kuadran, sektor yang masuk dalam kuadran I sektor maju dan tumbuh dengan pesat adalah: sektor pertanian kehutanan dan perikanan, sektor pengadaan listrik dan gas, sektor perdagangan besar dan eceran, reparasi sepeda motor dan mobil, sektor administrasi pemerintahan, pertahanan dan jaminan sosial wajib, sektor jasa pendidikan. Kuadran II sektor maju tapi tertekan adalah: sektor konstruksi, sektor jasa keuangan dan asuransi, sektor jasa perusahaan. Kuadran III sektor potensial atau masih dapat berkembang adalah: sektor industri pengolahan, sektor pengadaan air dan pengolahan sampah, limbah dan daur ulang, sektor informasi dan komunikasi, sektro jasa kesehatan dan kegiatan sosial, sektor jasa lainnya. Kuadran IV sektor relatif tertinggal adalah: sektor pertambangan dan penggalian, sektor transportasi dan pergudangan, sektor penyediaan akomodasi dan makan minum sektor real estate.
\end{abstract}

Kata kunci : Location Quotien, Shift Share, Tipologi Klassen

\begin{abstract}
This study aims to analyze which sectors are the leading sectors in Sumbawa Regency in 2011-2016, to know the economic structure (National Share, Proportional Shift and Differential Shift) of Sumbawa Regency in 2011-2016, to find out the economic sector growth in Sumbawa Regency in 2011 -2016. The analytical tool used is analysis of Location Quotient (LQ), Shift Share analysis and Klassen Typology analysis. Based on the analysis tools above, it was found that the leading sectors in Sumbawa Regency in 2011-2016 were: agriculture, forestry and fisheries sector, construction sector, corporate services sector, electricity and gas procurement sector, large and retail trade sector, motorcycle and car repair, financial and insurance services sector, government administration, defense and social security mandatory, and the education services sector. The biggest part of the economic structure of Sumbawa Regency is the agricultural sector of forestry and fisheries, while the smallest is the sector of water supply and processing of waste, waste and recycling. Proportional Shift has ten sectors that are negatively marked and have seven sectors that are positively marked. Shift differential has eleven sectors that are negative and have six positive sectors. And the economic growth of Sumbawa Regency is four quadrants, the sectors included in the advanced and rapidly growing quadrant I are: agriculture, forestry and fisheries, electricity and gas procurement sector, large and retail trade sector, motorcycle and car repair, government administration sector, mandatory defense and social security, the education services sector. Quadrant II of the advanced but depressed sector are: the construction sector, the financial services and insurance sector, the corporate services sector. Quadrant III potential or still developing sectors are: manufacturing industry sector, water supply and waste processing, waste and recycling sectors, information and communication sector, health services sector and social activities, other service sectors. Quadrant IV in the relatively lagging sector is: the mining and quarrying sector, the transportation and warehousing sector, the sector providing accommodation and drinking, the real estate sector.
\end{abstract}

Keywords: Location Quotien, Shift Share, Klassen Typology 


\section{PENDAHULUAN}

\section{Latar Belakang}

Secara teoritis potensi ekonomi dapat di terjemahkan dalam dua bentuk yakni potensi dan ekonomi, potensi itu sendiri adalah suatu kemampuan yang sudah ada dan mempumyai kemungkinan untuk bisa di kembangkan lagi untuk menjadi lebih baik, sedangkan ekonomi adalah ilmu sosial yang berhubuhan dengan produksi, distribusi dan konsumsi terhadap barang dan jasa. Jadi dapat di katakan bahwa potensi ekonomi adalah suatu kemampuan ekonomi suatu wilayah dalam memproduksi dan mendistribusikan barang dan jasanya yang mempunyai kemungkinan untuk dapat di kembangkan lagi oleh pemerintah. Menurut Majdi (2007) potensi yaitu kemampuan, kesanggupan, kekuatan ataupun daya yang mempuyai kemungkinan untuk bisa dikembangkan lagi menjadi bentuk yang lebih besar. Sedangkan menurut Adam Smith untuk mengalokasiakan sumber-sumber daya yang terbatas guna mencapai tujuan tertentu secara sistematis mempelajari tingkah laku manusia dalam usahanya adalah pengertian ekonomi.

Dalam suatu wilayah pasti memiliki potensi ekonomi unggulan masing-masing, dalam hal ini sektor unggulan. Bisa di katakan sebagai sektor unggulan apabila sektor tersebut mampu bersaing dengan sektor yang sama di wilayah lain. Menurut Rachbini (2001) sektor unggulan memiliki potensi lebih besar untuk tumbuh di bandingkan dengan sektor lainnya dalam suatu wilayah di karenakan adanya faktor pendukung terhadap sektor unggulan tersebut yaitu akumulasi modal, pertumbuhan penyerapan tenaga kerja, dan kemajuan teknologi. Penciptaan peluang investasi juga dapat dilakukan dengan memberdayakan potensi sektor unggulan yang dimiliki oleh wilayah yang bersangkutan.

Sektor unggulan yang di maksud dalam penelitian ini sama halnya dengan sektor basis yaitu kegiatan yang berorientasi ekspor barang dan jasa keluar dari batas wilayah perekonomian yang bersangkutan, sedangkan sektor non basis yaitu kegiatan yang berorientasi lokal yang menyediakan barang dan jasa untuk kebutuhan masyarakat dalam batas wilayah perekonomian yang bersangkutan. Menurut Glasson (1977) kegiatan ini tidak mengekpor barang dan jasa, jadi daerah pasar dan luas lingkup produksi mereka yang terutama adalah bersifat lokal. Bertambahnya kegiatan basis di suatu daerah akan berpengaruh terhadap peningkatan arus pendapatan daerah dan akan menambah permintaan barang dan jasa di daerah tersebut, yang kemudian akan berdampak terhadap tumbuhnya kegiatan non basis. Begitupun sebaliknya jika kegiatan basis berkurang maka akan berdampak pada berkurangnya pendapatan yang mengalir kedalam daerah, sehingga akan mengakibatkan turunnya permintaan terhadap produk kegiatan non basis.

Beberapa dearah tentunya memiliki sektor-sektor ekonomi yang menonjol masing-masing yang dapat menunjang pertumbuhan ekonomi suatu dareah tersebut salah satunya adalah Kabupaten Sumbawa. Mengetahui lebih jelas mengenai pertumbuhan dan perkembangan sektor-sektor ekonomi di Kabupaten Sumbawa, dapat dilihat dari data PDRB di bawah ini: 
Tabel 1.1 Jumlah PDRB (Produk Domestik Regional Bruto) Kabupaten Sumbawa Atas Dasar Harga Konstan Tahun 2011 -2016 (Juta Rp)

\begin{tabular}{|c|c|c|c|c|c|c|}
\hline \multirow{2}{*}{ KATEGORI } & \multicolumn{6}{|c|}{ PDRB Harga Konstan 2010 (Juta Rupiah) } \\
\hline & 2011 & 2012 & 2013 & 2014 & 2015 & 2016 \\
\hline $\begin{array}{l}\text { Pertanian,Kehutanan,dan } \\
\text { Perikanan }\end{array}$ & 2.651 .399 & 2.843 .374 & 3.021 .694 & 3.212 .657 & 3.432 .446 & 3.537 .543 \\
\hline Pertambangan dan Penggalian & 209.601 & 221.615 & 236.028 & 251.975 & 268.638 & 289.896 \\
\hline Industri Pengolahan & 161.079 & 168.255 & 176.080 & 184.759 & 191.379 & 199.574 \\
\hline Pengadaan Listrik dan Gas & 4.789 & 5.489 & 6.529 & 9.111 & 8.689 & 9.578 \\
\hline $\begin{array}{l}\text { Pengadaan Air dan Pengelolaan } \\
\text { Sampah, Limbah dan Daur } \\
\text { Ulang }\end{array}$ & 3.655 & 3.832 & 4.024 & 4.367 & 4.548 & 4.766 \\
\hline Konstruksi & 932.604 & 968.882 & 1.026 .249 & 1.090 .429 & 1.166 .105 & 1.248 .252 \\
\hline $\begin{array}{l}\text { Perdagangan Besar dan Eceran; } \\
\text { Reparasi Sepeda Motor dan } \\
\text { Mobil }\end{array}$ & 925.023 & 1.007 .658 & 1.095 .106 & 1.189 .137 & 1.252 .112 & 1.347 .032 \\
\hline Transportasi dan Pergudangan & 264.620 & 278.287 & 293.327 & 309.195 & 331.950 & 350.604 \\
\hline $\begin{array}{l}\text { Penyediaan Akomodasi dan } \\
\text { Makan Minum }\end{array}$ & 77.047 & 82.042 & 87.606 & 93.988 & 98.877 & 106.510 \\
\hline Informasi dan Komunikasi & 84.822 & 96.351 & 104.750 & 115.189 & 126.097 & 136.747 \\
\hline Jasa Keuangan dan Asuransi & 203.161 & 229.589 & 247.608 & 268.335 & 292.666 & 325.015 \\
\hline Real Estate & 138.174 & 144.206 & 152.008 & 161.644 & 172.022 & 181.946 \\
\hline Jasa Perusahaan & 15.231 & 16.178 & 17.194 & 18.452 & 19.487 & 20.764 \\
\hline $\begin{array}{l}\text { Administrasi Pemerintahan, } \\
\text { Pertahanan dan Jaminan Sosial } \\
\text { Wajib }\end{array}$ & 441.153 & 454.227 & 468.338 & 484.376 & 501.087 & 512.844 \\
\hline Jasa Pendidikan & 298.190 & 318.685 & 341.010 & 364.690 & 390.839 & 416.586 \\
\hline $\begin{array}{l}\text { Jasa Kesehatan dan Kegiatan } \\
\text { Sosial }\end{array}$ & 83.362 & 87.679 & 94.507 & 101.127 & 108.074 & 114.653 \\
\hline Jasa Lainnya & 112.447 & 120.437 & 128.195 & 137.748 & 146.027 & 156.319 \\
\hline PDRB & 6.606 .355 & 7.046 .787 & 7.500 .252 & 7.997 .178 & 8.511 .042 & 8.958 .630 \\
\hline
\end{tabular}

Sumber: BPS Kabupaten Sumbawa

Dari tabel 1.1 di atas dapat di jabarkan bahwa PDRB Kabupaten Sumbawa selama kurun waktu 2011-2016 terus mengalami peningkatan yaitu Rp. 6.606.355 pada tahun 2011, sampai dengan tahun 2016 sebesar Rp. 8.958.630. Hal ini menggambarkan bahwa perekonomian di Kabupaten Sumbawa mengalami peningkatan yang signifikan. Meningkatnya perekonomian di Kabupaten Sumbawa dapat dilihat dari peningkatan nilai tambah berbagai sektor-sektor ekonomi yang dapat dilihat pada data PDRB di atas.

Sektor pertanian masih mendominasi dengan nilai tambah terhadap pembentukan PDRB Kabupaten Sumbawa paling besar di antara sektor-sektor ekonomi lainnya. Tingginya nilai tambah sektor pertanian karena sumbangan sub sektor tanaman pangan. Hal ini juga didukung dengan keadaan tofografi pulau Sumbawa yang didominasi oleh perbukitan dan pegunungan yang relatif tinggi dan berhutan. (BPS, 2016)

Sektor yang paling rendah nilai tambah terhadap pembentukan PDRB Kabupaten Sumbawa yaitu sektor pengadaan air, pengolahan sampah, limbah dan daur ulang. Rendahnya nilai tambah sektor ini di karenakan masih kurangnya pendistribusian air melalui berbagai saluran pipa untuk kebutuhan rumah tangga dan industri. (BPS, 2016)

Sehingga muncul pertanyaan sektor-sektor manakah yang menjadi sektor unggulan, bagaimana strukturstruktur ekonomi serta pertumbuhan sektor perekonomian yang ada di Kabupaten Sumbawa untuk dapat dikembangkan. 


\section{Rumusan Masalah}

Berdasarkan uraian latar belakang diatas maka permasalahan yang diajukan adalah:

1. Sektor manakah yang menjadi sektor unggulan di Kabupaten Sumbawa tahun 2011-2016.

2. Bagaimana struktur ekonomi (National Share, Propotional Shift dan Differential Shift) Kabupaten Sumbawa tahun 2011-2016.

3. Bagaimana pertumbuhan sektor perekonomian yang ada di Kabupaten Sumbawa tahun 2011-2016.

\section{Tujuan Penelitian}

Dengan mengacu pada latar belakang dan rumusan masalah maka tujuan penelitiannya yaitu:

1. Menganalisa sektor manakah yang menjadi sektor unggulan di Kabupaten Sumbawa tahun 2011-2016.

2. Untuk mengetahui bagaimana struktur ekonomi (National Share, Propotional Shift dan Differential Shift) Kabupaten Sumbawa tahun 2011-2016.

3. Untuk mengetahui bagaimana pertumbuhan sektor perekonomian yang ada di Kabupaten Sumbawa tahun 2011-2016.

\section{TINJAUAN PUSTAKA}

\section{Pengertian Sektor Unggulan}

Sektor unggulan berkaitan dengan suatu perbandingan, bisa dikatakan sebagai sektor unggulan apabila sektor tersebut bisa bersaing dengan sektor yang sama di wilayah tertentu, baik itu perbandingan berskala regional, nasional maupun internasional. Menurut Sambodo yang dikutif Ghufron dalam Savitri (2008) sektor unggulan adalah sektor yang mempunyai keunggulan/kriteria yang keberadaannya saat ini telah berperan besar bagi perkembangan perekonomian suatu wilayah. Selanjutnya faktor ini berkembang lebih lanjut melalui kegiatan investasi dan menjadi tumpuan kegiatan ekonomi. Hal ini didasarkan atas seberapa besar peranan sektor tersebut dalam perekonomian daerah.

\section{Konsep Basis Ekonomi}

Teori Basis Ekonomi (economic base theory) mendasarkan pandangannya bahwa besarnya peningkatan ekspor dari suatu wilayah menentukan laju pertumbuhan ekonomi suatu wilayah tersebut. Kelompok kegiatan ekonomi yaitu kegiatan basis dan kegiatan non basis. Yang dapat mendorong pertumbuhan ekonomi wilayah hanya kegiatan basis (Tarigan, Edisi Revisi: 28)

\section{Teori Pertumbuhan Ekonomi}

Pertumbuhan ekonomi yaitu perubahan suatu tingkat kegiatan ekonomi yang berlaku dari tahun ketahun. Perekonomian dikatakan mengalami pertumbuhan apabila tingkat kegiatan ekonomi yang di capai lebih tinggi daripada masa sebelumnya. Oleh sebab itu ukuran yang selalu digunakan untuk memberikan suatu gambaran kasar mengenai pertumbuhan ekonomi yang dicapai suatu Negara adalah tingkat pertumbuhan pendapatan nasional riil (Sukirno, 2012:423)

\section{Teori Pembangunan Ekonomi Daerah}

Pembangunan ekonomi daerah adalah suatu proses untuk menciptakan suatu lapangan kerja baru dan merangsang perkembangan kegiatan ekonomi (pertumbuhan ekonomi) dalam wilayah tersebut dimana pemerintah daerah dan masyarakat mengelolah sumber daya yang ada dan membentuk suatu pola kemitraan antara pemerintah daerah dengan sektor swasta (Subandi, 2012:133).

\section{Analisis Location Quotent}

Location Quotient digunakan dalam analisis ekonomi regional dengan tujuan untuk mengetahui potensi sektor-sektor ekonomi pada suatu daerah tertentu. "Location Qoutient (kuosien lokasi) adalah suatu perbandingan tentang besarnya peranan suatu sektor/industri di suatu daerah terhadap besarnya peranan sektor/industri tersebut secara nasional" (Tarigan, Edisi Revisi : 82)

Nilai dari Location Quotient (LQ) adalah (Tarigan, Edisi revisi : 82-83) :

1. LQ>1, artinya peran sektor tersebut lebih besar di daerah daripada nasional.

2. $\mathrm{LQ}<1$, artinya peran sektor tersebut lebih kecil di daerah daripada nasional.

3. $\mathrm{LQ}=1$, artinya peran sektor tersebut sama baiknya di daerah ataupun nasional.

\section{Analisis Shift Share}

Shift share merupakan alat analisis yang membandingkan laju pertumbuhan berbagai sektor di daerah dengan wilayah nasional. Akan tetapi, metode ini lebih tajam dibandingkan dengan metode LQ. 
Metode LQ tidak menjelaskan faktor penyebab perubahan sedangkan metode shift share memperinci penyebab perubahan atas beberapa variabel. "Analisis shift share perubahan struktur industri suatu daerah dalam pertumbuhannya dari satu kurun waktu ke kurun waktu berikutnya yang disebabkan oleh metode pengisolasian berbagai faktor". (Tarigan, Edisi Revisi:86)

Analisis shift share memiliki 3 komponen (Tarigan, Edisi Revisi: 86-87), yaitu:

1. National Share (NS), untuk mengethui pergesern struktur perekonomiansuatu daerah uang di pengaruhi oleh pergeseran perekonomian nasioanl.

2. Proportional Shift $(\mathrm{P})$, adalah pertumbuhan nilai tambah bruto suatu sektor dibandingkan total sektor di tingkat nasional.

3. Differential Shift (D), adalah perbedaan atara pertumbuhan perekonomian satu daerah dengan nilai tambah bruto sektor yang sama di tingkat nasional.

\section{Analisis Tipologi Klassen}

Untuk mengklasifikasi posisi sektor perekonomian suatu daerah di gunakan analisis tipologi klassen dan tentunya dengan memperhatikan posisi sektor perekonomian nasional sebagai daerah referensi. "Untuk mengetahui klasifikasi sektor perekonomian suatu wilayah, digunakan salah satu alat analisis ekonomi regional yaitu tipologi klassen". (Sjafrizal, 2008:180).

Analisis Tipologi Klassen menghasilkan empat klasifikasi sektor dengan karakteristik yang berbeda sebagai berikut (Sjafrizal, 2008:180):

1. Sektor yang maju dan tumbuh dengan pesat (developed sector)

(Kuadran I). Kuadran ini merupakan kuadran yang rata-rata pertumbuhan sektor daerah analisis (si) lebih besar dibandingkan rata-rata pertumbuhan sektor daerah acuan (s) dan rata-rata kontribusi sektor daerah analisis (ski) lebih besar dibandingkan ratarata kontribusi sektor daerah acuan (sk). Klasifikasi ini dilambangkan dengan $\mathrm{si}>\mathrm{s}$ dan ski $>$ sk.

2. Sektor maju tapi tertekan (stagnant sector)

(Kuadran II). Kuadran ini merupakan kuadran yang rata-rata pertumbuhan sektor daerah analisis (si) lebih kecil dibandingkan rata-rata pertumbuhan sektor daerah acuan (s) dan rata-rata kontribusi sektor daerah analisis (ski) lebih besar dibandingkan rata- rata kontribusi sektor daerah acuan (sk). Klasifikasi ini dilambangkan dengan $\mathrm{si}<\mathrm{s}$ dan $\mathrm{ski}>\mathrm{sk}$.

3. Sektor potensial atau masih dapat berkembang (developing sector)

(Kuadran III). Kuadran ini merupakan kuadran yang rata-rata pertumbuhan sektor daerah analisis (si) lebih besar dibandingkan rata-rata pertumbuhan sektor daerah acuan (s) dan rata-rata kontribusi sektor daerah analisis (ski) lebih kecil dibandingkan ratarata kontribusi sektor daerah acuan (sk). Klasifikasi ini dilambangkan dengan si $>$ s dan ski $<$ sk.

\section{Sektor relatif tertinggal (underdeveloped sector)}

(Kuadran IV). Kuadran ini merupakan kuadran yang rata-rata pertumbuhan sektor daerah analisis (si) lebih kecil dibandingkan rata-rata pertumbuhan sektor daerah acuan (s) dan rata-rata kontribusi sektor daerah analisis (ski) lebih kecil dibandingkan ratarata kontribusi sektor daerah acuan (sk). Klasifikasi ini dilambangkan dengan $\mathrm{si}<\mathrm{s}$ dan $\mathrm{ski}<\mathrm{sk}$.

\section{METODE PENELITIAN}

\section{Jenis dan Sumber Data}

Sumber data yang digunakan dalam penelitian ini adalah data sekunder yang diperoleh dari Badan Pusat Statistik (BPS). Data yang dugunakan di sini adalah data PDRB Kabupaten Sumbawa dan PDRB Provinsi Nusa Tenggara Barat atas dasar harga konstan periode 2011-2016, disertai dengan data-data sekunder lain yang relevan dengan tujuan penulisan skripsi.

\section{Teknik Pengumpulan Data}

Teknik pengumpulan data yang digunakan dalam penelitian ini adalah sebagai berikut:

\section{Dokumenter}

Dokumenter adalah teknik pengumpulan data dengan cara mencatat data-data yang dipublikasikan pada kantor atau instansi yang terkait dengan masalah yang diteliti.

\section{Studi Kepustakaan}

Studi kepustakaan yaitu teknik pengumpulan data dengan cara membaca dan mencatat data-data yang dibutuhkan di mana data-data tersebut bersumber dari bahan bacaan yang berkaitan dengan penelitian ini. 


\section{Metode Analisis}

Dalam penelitian ini di pergunaka tiga teknik analisis sebagai berikut: Untuk mengetahui sektorsektor apa saja yang termasuk sektor unggulan di kabupaten Sumbawa, maka metode analisis yang digunakan analisis LQ, untuk mengetahui struktur ekonomi (National Share, Proportional Shif dan Differential Shift) di kabupaten Sumbawa digunakan analisis shift share dan untuk mengetahui pertumbuhan sektor perekonomian di kabupaten Sumbawa digunakan analisis tipologi klassen.

\section{Metode Analisis LQ}

Untuk mengetahui tingkat spesialisasi sektor unggulan di Kabupaten Sumbawa adalah Location Quotient (LQ) dengan rumus (Tarigan, Edisi Revisi : 82) sebagai berikut:

$$
\mathrm{LQ}=(\mathrm{X} / \mathrm{\text {irr }}) /(\mathrm{X} / \mathrm{X} \mathrm{X} \mathrm{n})
$$

\section{Dimana:}

LQ = Location Quotient (Potensi Ekonomi)

$\mathrm{X}_{\mathrm{ir}}=$ nilai tambah bruto sektor i dalam PDRB Kabupaten Sumbawa

$\mathrm{X}_{\mathrm{r}}=$ nilai PDRB di Kabupaten Sumbawa

$\mathrm{X}_{\text {in }}=$ nilai tambah bruto sektor i dalam PDRB provinsi NTB

$\mathrm{X}_{\mathrm{n}}=$ nilai PDRB provinsi NTB

\section{Metode Analisis Shift Share}

Analisis shift share dengan rumus (Tarigan, Edisi Revisi : 88)

$$
\begin{aligned}
& \Delta E_{r, i, t}=\left(N_{i}+P_{r, i}+D_{r, i}\right) \\
& N s_{i, t}=E_{r, i, t-n}\left(E_{N, t} / E_{N, t-n}\right)-E_{r, i, t-n} \\
& P_{r, i, t}=\left\{\left(E_{N, i, t} / E_{N, i, t-n}\right)-\left(E_{N . t} / E_{N, i, t-n}\right)\right\} \times E_{r, i, t-n} \\
& D_{r, i, t}=\left\{E_{r, i, t}-\left(E_{N, i, t} / E_{N, i, t-n}\right) E_{r, i, t-n}\right\}
\end{aligned}
$$

Di mana:

$$
\begin{array}{ll}
\Delta \mathrm{E}_{\mathrm{r}, \mathrm{i}, \mathrm{t}} & =\text { Tambahan semua sektor } \\
\mathrm{Ns} & =\text { National share } \\
\mathrm{E}_{\mathrm{r}} & =\text { PDRB Sumbawa } \\
\mathrm{E}_{\mathrm{N}} & =\text { PDRB NTB }
\end{array}
$$

$$
\begin{array}{ll}
\mathrm{P}_{\mathrm{r}} & =\text { Proportional shift } \\
\mathrm{D}_{\mathrm{r}} & =\text { Differential shift } \\
\mathrm{N} & =\text { Nasional } \\
\mathrm{r} & =\text { Regional } \\
\mathrm{i} & =\text { Sektor } \\
\mathrm{t} & =\text { Tahun Awal } \\
\mathrm{t}-\mathrm{n} & =\text { Tahun Akhir }
\end{array}
$$

\section{Metode Analisis Tipologi Klassen}

Tabel 3.1 Klasifikasi sektor PDRB menurut tipologoi klassen

\begin{tabular}{|c|c|}
\hline $\begin{array}{c}\text { Kuadran I } \\
\text { Sektor yang maju dan } \\
\text { tumbuh dengan pesat } \\
\text { (developed sector) }\end{array}$ & $\begin{array}{c}\text { Kuadran II } \\
\text { Sektor maju tapi } \\
\text { tertekan (stagnant } \\
\text { sector) }\end{array}$ \\
\hline $\begin{array}{c}\text { Kektor potensial atau } \\
\text { masih dapat } \\
\text { berkembangkan } \\
\text { (developing sector) }\end{array}$ & $\begin{array}{c}\text { Kuadran IV } \\
\text { Sektor relative } \\
\text { tertinggal } \\
\text { (underdeveloped } \\
\text { sector) }\end{array}$ \\
\hline
\end{tabular}

Sumber: Sjafrizal, (2008: 180)

Ketengan:

Kuadran I : Sektor Maju: si > s dan ski > sk

Kuadran II : Sektor Maju tapi Tertekan si < s dan s > sk

Kuadran III : Sektor Potensial si > s dan ski $<$ sk

Kuadran IV : Sektor Relatif Tertinggal si < s dan ski $<\mathrm{sk}$

Di mana:

si : Rata-Rata Pertumbuhan sektor i di kabupaten Sumbawa.

s : Rata-Rata Pertumbuhan sektor i di provinsi NTB.

ski : Rata-Rata Kontribusi sektor i di kabupaten Sumbawa.

sk : Rata-Rata Kontribusi sektor i di provinsi NTB. 


\section{HASIL DAN PEMBAHASAN}

Untuk mengetahui besar kacilnya peranan suatu sektor dalam perekonomian di Kabupaten Sumbawa dapat diketahui nilai LQ sektor-sektor ekonomi dari tujuh belas sektor ekonomi yang ada. Dapat dilihat pada tabel 4.1 dibawah ini

Tabel 4.1. Nilai Location Quotient Sektor Ekonomi Kabupaten Sumbawa Atas Dasar Harga Konstan Tahun $2011-2016$

\begin{tabular}{|l|c|c|c|c|c|c|}
\hline \multirow{2}{*}{ Lapangan Usaha } & \multicolumn{5}{|c|}{ LQ } \\
\cline { 2 - 7 } & 2011 & 2012 & 2013 & 2014 & 2015 & 2016 \\
\hline $\begin{array}{l}\text { Pertanian,Kehutanan,dan } \\
\text { Perikanan }\end{array}$ & 1.723307283 & 1.631483716 & 1.658580908 & 1.665069409 & 1.903949027 & 1.934912091 \\
\hline $\begin{array}{l}\text { Pertambangan dan } \\
\text { Penggalian }\end{array}$ & 0.145332303 & 0.193382861 & 0.195078592 & 0.205703062 & 0.121201539 & 0.123482043 \\
\hline Industri Pengolahan & 0.501326409 & 0.463855809 & 0.462738903 & 0.463321657 & 0.532519298 & 0.530095064 \\
\hline Pengadaan Listrik dan Gas & 1.272030518 & 1.200324358 & 1.271862759 & 1.253544616 & 1.355798356 & 1.350577998 \\
\hline $\begin{array}{l}\text { Pengadaan Air dan } \\
\text { Pengelolaan Sampah, } \\
\text { Limbah dan Daur Ulang }\end{array}$ & 0.678714616 & 0.634448048 & 0.630542765 & 0.629833405 & 0.723081066 & 0.726264021 \\
\hline Konstruksi & 1.549201684 & 1.432758427 & 1.425434426 & 1.385801745 & 1.58065087 & 1.565736892 \\
\hline $\begin{array}{l}\text { Perdagangan Besar dan } \\
\text { Eceran; Reparasi Sepeda } \\
\text { Motor dan Mobil }\end{array}$ & 1.231176863 & 1.130264871 & 1.125258226 & 1.119301421 & 1.279043741 & 1.284991632 \\
\hline $\begin{array}{l}\text { Transportasi dan } \\
\text { Pergudangan }\end{array}$ & 0.609573524 & 0.555303044 & 0.54966008 & 0.531700545 & 0.611835984 & 0.609597022 \\
\hline $\begin{array}{l}\text { Penyediaan Akomodasi } \\
\text { dan Makan Minum }\end{array}$ & 0.737657332 & 0.675260617 & 0.655807879 & 0.649029471 & 0.739414685 & 0.725104481 \\
\hline Informasi dan Komunikasi & 0.508282179 & 0.626482248 & 0.626658626 & 0.627223856 & 0.725122581 & 0.726737424 \\
\hline $\begin{array}{l}\text { Jasa Keuangan dan } \\
\text { Asuransi }\end{array}$ & 1.217409585 & 1.120785124 & 1.093551945 & 1.085095416 & 1.238678663 & 1.231293429 \\
\hline Real Estate & 0.777146917 & 0.701809632 & 0.677828605 & 0.672389209 & 0.76633402 & 0.767480286 \\
\hline Jasa Perusahaan & 1.480425343 & 1.327878222 & 1.304147632 & 1.286996347 & 1.470434103 & 1.472276355 \\
\hline $\begin{array}{l}\text { Administrasi } \\
\begin{array}{l}\text { Pemerintahan, Pertahanan } \\
\text { dan Jaminan Sosial Wajib }\end{array}\end{array}$ & 1.166694839 & 1.0993798 & 1.087106516 & 1.056342187 & 1.205794554 & 1.208210488 \\
\hline Jasa Pendidikan & 1.06841731 & 1.012922889 & 1.010010931 & 0.99830754 & 1.141145386 & 1.160437775 \\
\hline $\begin{array}{l}\text { Jasa Kesehatan dan } \\
\text { Kegiatan Sosial }\end{array}$ & 0.671331225 & 0.628436595 & 0.622202292 & 0.614192276 & 0.703360159 & 0.709707143 \\
\hline Jasa Lainnya & 0.827318002 & 0.799567808 & 0.778351623 & 0.765039649 & 0.873714495 & 0.884687794 \\
\hline Sumber
\end{tabular}

\section{Sumber : Data yang telah diolah}

Dilihat dari nilai LQ di atas dengan menggunakan harga konstan, yang menjadi sektor basis selama tahun 2011-2016 di Kabupaten Sumbawa adalah sektor pertanian, kehutanan, dan perikanan, sektor konstruksi, sektor jasa perusahaan, sektor pengadaan listrik dan gas, sektor perdagangan besar dan eceran, reparasi sepeda motor dan mobil, sektor jasa keuangan dan asuransi, sektor administrasi pemerintahan, pertahanan dan jaminan sosial wajib, dan sektor jasa pendidikan. Hal ini disebabkan karena nilai LQ nya lebih besar dari satu sedangkan sektor lainnya adalah sektor non basis karena nilai LQ nya kurang dari satu.

Guna mendapat nilai shift share maka langkahlangkahnya akan peneliti sajikan dalam tabel yaitu tabel 4.2 perhitungan national share, tabel 4.3 perhitungan proportional shift, dan 4.4 perhitungan differential shift. Perhitungan National Share di sajikan pada tabel 4.2 berikut ini: 
Tabel 4.2 Perhitungan Nasional Share

\begin{tabular}{|l|c|c|c|c|}
\hline \multicolumn{1}{|c|}{ Lapangan Usaha } & E r,i,t-n (a) & E Nt/E N,t-n (b) & $\mathrm{c}=\mathrm{a} \mathrm{x} \mathrm{b}$ & $\begin{array}{c}\text { National } \\
\text { Share }\end{array}$ \\
\hline Pertanian,Kehutanan,dan Perikanan & $2,651,399$ & 1.403226652 & 3720513.743 & $1,069,114.74$ \\
\hline Pertambangan dan Penggalian & 209,601 & 1.403226652 & 294117.7096 & $84,516.71$ \\
\hline Industri Pengolahan & 161,079 & 1.403226652 & 226030.3459 & $64,951.35$ \\
\hline Pengadaan Listrik dan Gas & 4,789 & 1.403226652 & 6720.052438 & $1,931.05$ \\
\hline $\begin{array}{l}\text { Pengadaan Air dan Pengelolaan } \\
\text { Sampah, Limbah dan Daur Ulang }\end{array}$ & 3,655 & 1.403226652 & 5128.793414 & $1,473.79$ \\
\hline Konstruksi & 932,604 & 1.403226652 & 1308654.789 & $376,050.79$ \\
\hline $\begin{array}{l}\text { Perdagangan Besar dan Eceran; } \\
\text { Reparasi Sepeda Motor dan Mobil }\end{array}$ & 925,023 & 1.403226652 & 1298016.928 & $372,993.93$ \\
\hline Transportasi dan Pergudangan & 264,620 & 1.403226652 & 371321.8367 & $106,701.84$ \\
\hline $\begin{array}{l}\text { Penyediaan Akomodasi dan Makan } \\
\text { Minum }\end{array}$ & 77,047 & 1.403226652 & 108114.4039 & $31,067.40$ \\
\hline Informasi dan Komunikasi & 84,822 & 1.403226652 & 119024.4911 & $34,202.49$ \\
\hline Jasa Keuangan dan Asuransi & 203,161 & 1.403226652 & 285080.9299 & $81,919.93$ \\
\hline Real Estate & 138,174 & 1.403226652 & 193889.4395 & $55,715.44$ \\
\hline Jasa Perusahaan & 15,231 & 1.403226652 & 21372.54514 & $6,141.55$ \\
\hline $\begin{array}{l}\text { Administrasi Pemerintahan, Pertahanan } \\
\text { dan Jaminan Sosial Wajib }\end{array}$ & 441,153 & 1.403226652 & 619037.6473 & $177,884.65$ \\
\hline Jasa Pendidikan & 298,190 & 1.403226652 & 418428.1555 & $120,238.16$ \\
\hline Jasa Kesehatan dan Kegiatan Sosial & 83,362 & 1.403226652 & 116975.7802 & $33,613.78$ \\
\hline Jasa Lainnya & 112,447 & 1.403226652 & 157788.6274 & $45,341.63$ \\
\hline PDRB & $6,606,355$ & 1.403226652 & 9270213.411 & $2,663,858.41$ \\
\hline
\end{tabular}

\section{Sumber: Data yang telah diolah}

Dari Tabel 4.3 diketahui bahwa sektor yang memiliki national share terbesar adalah sektor pertanian kehutanan dan perikanan 1,069,114.74 karena di pengaruhi oleh kebijakan dari tingkat nasional, salah satunya pembanguna ekonomi difokuskan ke tiga sektor yaitu sektor pertanian kehutanan dan perikanan, sektor pertambangan dan penggalian dan sektor perdagangan besar dan eceran, reparasi sepeda motor dan mobil, sedangkan yang terkecil adalah sektor Pengadaan Air, Pengelolaan Sampah, Limbah dan Daur Ulang dengan angka 1,473.79. Total National Share sebesar 2,663,858.41.

Tabel 4.3 Perhitungan Proportional Shift

\begin{tabular}{|c|c|c|c|c|c|}
\hline Lapangan Usaha & $\begin{array}{l}\text { E r,i,t-n } \\
\text { (a) }\end{array}$ & $\begin{array}{c}\text { E N,i,t/E N,i,t- } \\
n(b)\end{array}$ & $\begin{array}{c}\text { E N,t/E N,t- } \\
n(c)\end{array}$ & $d=b-c$ & $\begin{array}{l}\text { Proportional } \\
\text { Share }\end{array}$ \\
\hline $\begin{array}{l}\text { Pertanian,Kehutanan,dan } \\
\text { Perikanan }\end{array}$ & $2,651,399$ & 1.229635114 & 1.403226652 & -0.173591539 & -460260.4321 \\
\hline $\begin{array}{l}\text { Pertambangan dan } \\
\text { Penggalian }\end{array}$ & 209,601 & 1.684439251 & 1.403226652 & 0.281212599 & 58942.44195 \\
\hline Industri Pengolahan & 161,079 & 1.212495101 & 1.403226652 & -0.190731552 & -30722.84759 \\
\hline Pengadaan Listrik dan Gas & 4,789 & 1.949198139 & 1.403226652 & 0.545971487 & 2614.657452 \\
\hline $\begin{array}{l}\text { Pengadaan Air dan } \\
\text { Pengelolaan Sampah } \\
\text { Limbah dan Daur Ulang }\end{array}$ & 3,655 & 1.260977857 & 1.403226652 & -0.142248796 & -519.9193478 \\
\hline Konstruksi & 932,604 & 1.37038408 & 1.403226652 & -0.032842572 & -30629.11432 \\
\hline
\end{tabular}


Nusantara Journal of Economics

\begin{tabular}{|l|c|c|c|c|c|}
$\begin{array}{l}\text { Perdagangan Besar dan } \\
\text { Eceran; Reparasi Sepeda } \\
\text { Motor dan Mobil }\end{array}$ & 925,023 & 1.443755526 & 1.403226652 & 0.040528874 & 37490.1402 \\
\hline $\begin{array}{l}\text { Transportasi dan } \\
\text { Pergudangan }\end{array}$ & 264,620 & 1.370962553 & 1.403226652 & -0.0322641 & -8537.726063 \\
\hline $\begin{array}{l}\text { Penyediaan Akomodasi } \\
\text { dan Makan Minum }\end{array}$ & 77,047 & 1.455247488 & 1.403226652 & 0.052020836 & 4008.049324 \\
\hline Informasi dan Komunikasi & 84,822 & 1.486596733 & 1.403226652 & 0.083370081 & 7071.616971 \\
\hline $\begin{array}{l}\text { Jasa Keuangan dan } \\
\text { Asuransi }\end{array}$ & 203,161 & 1.636765077 & 1.403226652 & 0.233538424 & 47445.89986 \\
\hline Real Estate & 138,174 & 1.379749399 & 1.403226652 & -0.023477253 & -3243.945947 \\
\hline Jasa Perusahaan & 15,231 & 1.418495322 & 1.403226652 & 0.015268669 & 232.5571035 \\
\hline $\begin{array}{l}\text { Administrasi } \\
\text { Pemerintahan, Pertahanan } \\
\text { dan Jaminan Sosial Wajib }\end{array}$ & 441,153 & 1.161606007 & 1.403226652 & -0.241620646 & -106591.6227 \\
\hline Jasa Pendidikan & 298,190 & 1.331002238 & 1.403226652 & -0.072224415 & -21536.59823 \\
\hline $\begin{array}{l}\text { Jasa Kesehatan dan } \\
\text { Kegiatan Sosial }\end{array}$ & 83,362 & 1.346241892 & 1.403226652 & -0.05698476 & -4750.36357 \\
\hline Jasa Lainnya & 112,447 & 1.345223564 & 1.403226652 & -0.058003088 & -6522.273291 \\
\hline PDRB & $6,606,355$ & 1.403226652 & 1.403226652 & 0 & 0 \\
\hline
\end{tabular}

Sumber: Data yang telah diolah.

Dari table 4.4 diketahui angka Proportional Shift memiliki tanda yang negatif. Hal ini terjadi karena tingkat pertumbuhan di daerah lebih lambat dibandingkan nasional. Sektor yang memiliki nilai negatif yaitu: sektor pertanian, kehutanan, dan perikanan, sektor administrasi pemerintahan, pertahanan dan jaminan sosial wajib, sektor industri pengolahan. sektor konstruksi, sektor jasa pendidikan, sektor transportasi dan pergudangan, sektor jasa lainnya, sektor jasa kesehatan dan kegiatan sosial, sektor real estate, dan sektor pengadaan air dan pengelolaan sampah limbah dan daur ulang. Kesepuluh sektor ini memiliki tingkat pertumbuhan di daerah lebih lambat dibandingkan nasional.

Ketujuh sektor lain yang memiliki nilai positif yaitu: sektor pertambangan dan penggalian, sektor jasa keuangan dan asuransi, sektor perdagangan besar dan eceran, reparasi sepeda motor dan mobil, sektor informasi dan komunikasi, sektor penyediaan akomodasi dan makan minum, sektor pengadaan listrik dan gas dan sektor jasa perusahaa. Ketujuh sektor ini memiliki tingkat pertumbuhan di daerah lebih cepat dibandingkan nasional

Tabel 4.4 Perhitungan Defferensial Shift

\begin{tabular}{|l|c|c|c|c|c|}
\hline \multicolumn{1}{|c|}{ Lapangan Usaha } & E r,i,t (a) & $\begin{array}{c}\text { E N,I,t/E N,i,t-n } \\
(\mathrm{b})\end{array}$ & E r,i,t-n ( c ) & d = b x c & $\begin{array}{c}\text { Differensial } \\
\text { Shift }\end{array}$ \\
\hline Pertanian,Kehutanan,dan Perikanan & $3,537,543.00$ & 1.229635114 & $2,683,878.00$ & 3300190.629 & 237352.3706 \\
\hline Pertambangan dan Penggalian & $289,896.00$ & 1.684439251 & $212,379.00$ & 357739.5237 & -67843.52375 \\
\hline Industri Pengolahan & $199,574.00$ & 1.212495101 & $161,802.00$ & 196184.1323 & 3389.867706 \\
\hline Pengadaan Listrik dan Gas & $9,578.00$ & 1.949198139 & $4,332.00$ & 8443.92634 & 1134.07366 \\
\hline $\begin{array}{l}\text { Pengadaan Air dan Pengelolaan } \\
\text { Sampah Limbah dan Daur ulang }\end{array}$ & $4,766.00$ & 1.260977857 & $3,717.00$ & 4687.054694 & 78.94530644 \\
\hline Konstruksi & $1,248,252.00$ & 1.37038408 & $939,945.00$ & 1288085.664 & -39833.66407 \\
\hline $\begin{array}{l}\text { Perdagangan Besar dan Eceran; } \\
\text { Reparasi Sepeda Motor dan Mobil }\end{array}$ & $1,347,032.00$ & 1.443755526 & $981,034.00$ & 1416373.259 & -6934.25856 \\
\hline Transportasi dan Pergudangan & $350,604.00$ & 1.370962553 & $269,206.00$ & 369071.3449 & -18467.34494 \\
\hline $\begin{array}{l}\text { Penyediaan Akomodasi dan Makan } \\
\text { Minum }\end{array}$ & $106,510.00$ & 1.455247488 & $81,606.00$ & 118756.9265 & -12246.9265 \\
\hline
\end{tabular}

NJE: Vol.01, No. 01, pp 1-13, 2019 
Nusantara Journal of Economics

\begin{tabular}{|l|c|c|c|c|c|} 
Informasi dan Komunikasi & $136,747.00$ & 1.486596733 & $84,590.00$ & 125751.2176 & 10995.78237 \\
\hline Jasa Keuangan dan Asuransi & $325,015.00$ & 1.636765077 & $212,463.00$ & 347752.0185 & -22737.01851 \\
\hline Real Estate & $181,946.00$ & 1.379749399 & $146,156.00$ & 201658.6532 & -19712.65322 \\
\hline Jasa Perusahaan & $20,764.00$ & 1.418495322 & $15,456.00$ & 21924.26369 & -1160.263692 \\
\hline $\begin{array}{l}\text { Administrasi Pemerintahan, Pertahanan } \\
\text { dan Jaminan Sosial Wajib }\end{array}$ & $512,844.00$ & 1.161606007 & $488,327.00$ & 567243.5764 & -54399.57643 \\
\hline Jasa Pendidikan & $416,586.00$ & 1.331002238 & $321,872.00$ & 428412.3522 & -11826.35221 \\
\hline Jasa Kesehatan dan Kegiatan Sosial & $114,653.00$ & 1.346241892 & $85,564.00$ & 115189.8413 & -536.8412665 \\
\hline Jasa Lainnya & $156,319.00$ & 1.345223564 & $113,557.00$ & 152759.5522 & 3559.447762 \\
\hline PDRB & $8,958,630.00$ & 1.403226652 & $6,805,883.00$ & 9550196.418 & -591566.4181 \\
\hline
\end{tabular}

Sumber: Data yang telah diolah

Dari Tabel 4.4 kita ketahui bahwa nilai Differential Shift memiliki tanda negatif. Sektor yang memiliki tanda negatif yaitu: sektor pertambangan dan penggalian, sektor administrasi pemerintahan, pertahanan dan jaminan sosial wajib, sektor konstruksi, sektor jasa keuangan dan asuransi, sektor real estate, sektor transportasi dan pergudangan, sektor penyediaan akomodasi dan makan minum, sektor Jasa pendidikan, sektor jasa perusahaan, sektor perdagangan besar dan eceran; reparasi sepeda motor dan mobil, dan sektor jasa kesehatan dan kegiatan sosial. Kesebelas sektor ini kurang menguntungkan dalam perkembangan PDRB kabupaten Sumbawa karena keunggulan kompetitifnya negatif atau lebih lambat dibandingkan nasional.
Sektor yang memiliki tanda positif yaitu: sektor pertanian kehutanan dan peikanan, sektor informasi dan komunikasi, sektor industri pengolahan, sektor jasa lainnya, sektor pengadaan listrik dan gas dan sektor pengadaan air dan pengelolaan sampah limbah dan daur ulang. Keenam sektor ini sangat menguntungkan dalam perkembangan PDRB kabupaten Sumbawa karena keunggulan kompetitifnya positif atau lebih cepat dibandingkan nasional.

Berikut ini tabel 4.5 yang berisi Rata-rata pertumbuhan PDRB dan rata-rata kontribusi PDRB masing-masing sektor kabupaten Sumbawa dibandingkan dengan pertumbuhan sektor di provinsi Nusa Tenggara Barat diklasifikasikan ke dalam kategori menurut tipologi klassen.

Tabel 4.5 Rata-Rata Pertumbuhan dan Kontribusi PDRB Kabupaten Sumbawa dan Provinsi Nusa Tenggara Barat

\begin{tabular}{|l|c|c|c|c|}
\hline \multirow{2}{*}{ Lapangan Usaha } & \multicolumn{2}{|c|}{ Rata-Rata Pertumbuhan (\%) } & \multicolumn{2}{c|}{ Rata-Rata Kontribusi (\%) } \\
\cline { 2 - 5 } & Sumbawa & NTB & Sumbawa & NTB \\
\hline Pertanian,Kehutanan,dan Perikanan & 6.68 & 4.59 & 39.76 & 21.61 \\
\hline Pertambangan dan Penggalian & 7.66 & 13.7 & 3.21 & 24.39 \\
\hline Industri Pengolahan & 4.78 & 4.25 & 2.32 & 4.48 \\
\hline Pengadaan Listrik dan Gas & 20 & 18.98 & 0.09 & 0.07 \\
\hline $\begin{array}{l}\text { Pengadaan Air dan Pengelolaan Sampah, } \\
\text { Limbah dan Daur Ulang }\end{array}$ & 6.08 & 5.22 & 0.05 & 0.08 \\
\hline Konstruksi & 6.77 & 7.41 & 14.01 & 8.99 \\
\hline $\begin{array}{l}\text { Perdagangan Besar dan Eceran; Reparasi } \\
\text { Sepeda Motor dan Mobil }\end{array}$ & 9.12 & 8.88 & 14.6 & 11.56 \\
\hline Transportasi dan Pergudangan & 6.5 & 7.42 & 3.95 & 6.48 \\
\hline $\begin{array}{l}\text { Penyediaan Akomodasi dan Makan } \\
\text { Minum }\end{array}$ & 7.65 & 9.15 & 1.18 & 1.62 \\
\hline Informasi dan Komunikasi & 12.24 & 9.73 & 1.42 & 2.05 \\
\hline
\end{tabular}




\begin{tabular}{|l|c|c|c|c|} 
Jasa Keuangan dan Asuransi & 12 & 12.74 & 3.39 & 2.77 \\
\hline Real Estate & 6.34 & 7.6 & 2.06 & 2.67 \\
\hline Jasa Perusahaan & 7.27 & 8.4 & 0.23 & 0.16 \\
\hline $\begin{array}{l}\text { Administrasi Pemerintahan, Pertahanan } \\
\text { dan Jaminan Sosial Wajib }\end{array}$ & 3.25 & 3.23 & 6.13 & 5.15 \\
\hline Jasa Pendidikan & 7.94 & 6.62 & 4.59 & 4.1 \\
\hline Jasa Kesehatan dan Kegiatan Sosial & 7.51 & 6.93 & 1.27 & 1.84 \\
\hline Jasa Lainnya & 7.8 & 6.91 & 1.73 & 2.01 \\
\hline PDRB & 7.12 & 8.06 & 100 & 100 \\
\hline
\end{tabular}

\section{Sumber: Data yang telah diolah}

Berdasarkan tabel 4.5 bahwa selama kurun waktu 2011-2016 sektor ekonomi kabupaten Sumbawa yang memiliki tigkat pertumbuhan tertinggi adalah sektor pengadaan listrik dan gas dengan rata-rata 20 persen per tahun, sedangkan yang terendah adalah sektor administrasi pemerintahan, pertahanan dan jaminan sosial wajib dengan rata-rata 3,25 persen per tahun. Sementara tingkat pertumbuhan sektor ekonomi tertinggi di provinsi NTB adalah sektor pengadaan listrik dan gas dengan rata-rata 18,98 persen per tahun, sedangkan yang terendah adalah sektor administrasi pemerintahan, pertahanan dan jaminan sosial wajib dengan rata-rata 3,23 persen per tahun.

Sektor ekonomi yang memberikan kontribusi terbesar terhadap PDRB kabupaten Sumbawa selama kurun waktu 2011-2016 adalah sektor pertanian kehutanan dan perikanan dengan rata-rata 39,76 persen per tahun, sedangkan yang terendah adalah sektor pengadaan listrik dan gas dengan rata-rata 0,09 pesen per tahun. Sementara di tingkat provinsi NTB sector ekonomi yang memberikan kontribusi terbesar adalah sektor pertambangan dan penggalian dengan rata-rata 24,39 persen per tahun, sedangkan yang terendah adalah sektor pengadaan listrik dan gas dengan rata-rata 0,07 persen per tahun.

Hasil perhitungan tabel 4.5 selanjutnya akan dimasukkan ke dalam tabel matrik tipologi klassen untuk menndapatkan gambaran tentang tingkat kompetensi masig-masing sektor ekonomi kabupaten Sumbawa terhadap sektor ekonomi yang sama di tingkat provinsi NTB, dan dapat di lihat pada tabel 4.6.

\section{Tabel 4.6 Klasifikasi Sektor PDRB Menurut Tipologoi Klassen}

\begin{tabular}{|c|c|}
\hline \begin{tabular}{ll}
\multicolumn{1}{c}{ Kuadran I } \\
- Pertanian Kehutanan dan Perikanan. \\
- Pengadaan Listrik dan Gas. \\
Perdagangan Besar dan Eceran; Reparasi \\
Sepeda Motor dan Mobil. \\
- \\
Jaministrasi Pemerintahan, Pertahanan dan \\
- Jasa Pendidikan. Wajib. \\
\end{tabular} & \begin{tabular}{ll}
\multicolumn{1}{c}{ Kuadran II } \\
- $\quad$ Konstruksi. \\
- Jasa Keuangan dan Asuransi. \\
Jasa Perusahaan.
\end{tabular} \\
\hline $\begin{array}{l}\text { Kuadran III } \\
\text { - Industri Pengolahan. } \\
\text { - Pengadaan Air dan Pengelolaan Sampah, } \\
\text { Limbah dan Daur Ulang } \\
\text { - Informasi dan Komunikasi. } \\
\text { - Jasa Kesehatan dan Kegiatan Sosial. } \\
\text { - Jasa Lainnya. }\end{array}$ & \begin{tabular}{ll} 
& \multicolumn{1}{c}{ Kuadran IV } \\
- & Pertambangan dan Penggalian. \\
- & Pransportasi dan Pergudangan. \\
& Minum. \\
- & Real Estate.
\end{tabular} \\
\hline
\end{tabular}

Berdasarkan tipologi klassen pola pertumbuhan sektor ekonomi di kabupaten Sumbawa yang di kategorikan dalam kuadran I sektor yang maju dan tumbuh dengan pesat adalah sektor pertanian kehutanan dan perikanan, sektor pengadaan listrik dan gas, sektor perdagangann besar dan eceran, reparasi sepeda motor dan mobil, sektor administrasi pemerintahan, pertahanan dan jaminan sosial wajib dan sektor jasa pendidik 
Berdasarkan perbandingan rata-rata laju pertumbuhan dan rata-rata kontribusi PDRB di masing-masing sektor, yang termasuk dalam kuadran II sektor maju tapi tertekan yaitu: sektor konstruksi, sektor jasa keuangan dan asuransi dan sektor jasa perusahaan

Selanjutnya yang termasuk kuadran III sektor potensial atau masih dapat berkembang yaitu: sektor industri pengolahan, sektor pengadaan air dan pengolahan sampah, limbah dan daur ulang, sektor informasi dan komunikasi, sektor jasa kesehatan dan kegiatan sosial dan sektor jasa lainnya.

Dan yang terakhir yang termasuk dalam kuadran IV sektor relatif tertinggal yaitu: sektor pertambangan dan penggalian, sektor transportasi dan pergudangan, sektor penyediaan akomodasi dan makan minum, dan sektor real estate.

\section{PENUTUP}

\section{Kesimpulan}

Dari hasil analisis LQ di atas dapat di ketahui bahwa sektor basis di kabupaten Sumbawa selama priode 2011-2016 adalah sebagai berikut: (1). Sektor pertanian, kehutanan dan perikanan, (2). Sektor konstruksi, (3). Sektor jasa perusahaan, (4). Sektor pengadaan listrik dan gas, (5). Sektor perdagangan besar dan eceran, reparasi sepeda motor dan mobil, (6). Sektor jasa keuangan dan asuransi, (7). Sektor administrasi pemerintahan, pertahanan dan jaminan sosial wajib dan (8). Sektor jasa pendidikan.

Dari hasil analisis shift share di atas dapat di ketahui bahwa struktur ekonomi (National share, Proportional Shift dan Differential Shift) adalah sebagai berikut: Sektor yang memiliki National share terbesar adalah sektor Pertanian Kehutanan dan Perikanan sedangkan yang terkecil adalah Pengadaan Air, Pengelolaan Sampah, Limbah dan Daur Ulang. Sektor yang memiliki nilai negatif dalam Proportional Shift yaitu sektor pertanian, kehutanan, dan perikanan, sektor administrasi pemerintahan, pertahanan dan jaminan sosial wajib, sektor industri pengolahan. sektor konstruksi, sektor jasa pendidikan, sektor transportasi dan pergudangan, sektor jasa lainnya, sektor jasa kesehatan dan kegiatan sosial, sektor real estate, dan sektor pengadaan air dan pengelolaan sampah limbah dan daur ulang. Dan sektor yang memiliki nilai positif yaitu: sektor pertambangan dan penggalian, sektor jasa keuangan dan asuransi, sektor perdagangan besar dan eceran, reparasi sepeda motor dan mobil, sektor informasi dan komunikasi, sektor penyediaan akomodasi dan makan minum, sektor pengadaan listrik dan gas dan sektor jasa perusahaa. Sektor yang memiliki tanda negatif dalam Differential Shift yaitu sektor pertambangan dan penggalian, sektor administrasi pemerintahan, pertahanan dan jaminan sosial wajib, sektor konstruksi, sektor jasa keuangan dan asuransi, sektor real estate, sektor transportasi dan pergudangan, sektor penyediaan akomodasi dan makan minum, sektor Jasa pendidikan, sektor jasa perusahaan, sektor perdagangan besar dan eceran; reparasi sepeda motor dan mobil, dan sektor jasa kesehatan dan kegiatan sosial. Dan Sektor yang memiliki tanda positif yaitu: sektor pertanian kehutanan dan peikanan, sektor informasi dan komunikasi, sektor industri pengolahan, sektor jasa lainnya, sektor pengadaan listrik dan gas dan sektor pengadaan air dan pengelolaan sampah limbah dan daur ulang.

Dari hasil analisis tipologi klassen menunjukan bahwa pertumbuhan ekonomi kabupaten Sumbawa dibagi dalam 4 kuadran yakni kuadran I yaitu sektor yang maju dan tumbuh dengan pesat adalah sektor pertanian, kehutanan, dan perikanan, sektor pengadaan listrik dan gas, sektor perdagangan besar dan eceran; reparasi sepeda motor dan mobil, sektor administrasi pemerintahan, pertahanan dan jaminan sosial wajib, dan sektor jasa pendidikan. Di susul oleh sektor konstruksi, sektor jasa keuangan dan asuransi dan sektor jasa perusahaan pada kuadran II yaitu sektor maju tapi tertekan. Pada kuadran III yaitu sektor potensial atau masih dapat berkembang adalah sektor industri pengolahan, sektor pengadaan air dan pengolahan sampah, limbah dan daur ulang, sektor informasi dan komunikasi, sektor jasa kesehatan dan kegiatan sosial dan sektor jasa lainnya. Dan terakhir kuadran IV yaitu sektor relatif tertinggal adalah sektor pertambangan dan penggalian, sektor transportasi dan pergudangan, sektor penyediaan akomodasi dan makan minum, dan sektor real estate

\section{DAFTAR PUSTAKA}
Adam Smith. Teori Pertumbuhan Ekonomi Perencanaan dan Pembangunan. PT. Raja Grafindo Pustaka. Jakarta.

BPS, (2016). PDRB Kabupaten Sumbawa.

Glasson, John. 1977. Pengantar Perencanaan Regional. Terjemahan Paul Sitohang. Graha Ilmu. Jakarta.

Novrilasari, Dylla. (2008). Analisis Sektor Unggulan dalam Meningkatkan Perekonomian Dan Pembangunan Wilayah Kabupaten Kuantan Singingi. Institut Pertanian Bogor. Jawa Barat. 
Rachbini, Didik J, 2001. Pembangunan Ekonomi dan Sumber Daya Manusia. Gramedia Widiasarana Indonesia. Jakarta.

Savitri, Devi. (2008). Analisis Identifikasi Sektor Unggulan dan Struktur Ekonomi Pulau Sumatera. Institut Pertanian Bogor. Jawa Barat.

Sjafrizal. (2008). Ekomomi Regional: Teori dan Aplikasi. Baduose Media, Sumatera Barat. Hal. 180.

Subandi. (2012). Ekonomi Pembangunan. Bandung: Alfabeta. Hal. 133.

Sukirno, Sadono. (2012). Makro Ekonomi Teori Pengantar. Jakarta: PT Raja Grafindo Persada. Hal. 423.

Tarigan, Robinson. (Edisi Revisi). Ekonomi Regional: Teori dan Aplikasi. Jakarta: PT Bumi Aksara. 